\title{
The Challenge of Tax Avoidance for Social Justice in Taxation
}

\author{
Benjamin Alarie
}

Version Publisher's version

Citation Alarie, Benjamin, The Challenge of Tax Avoidance for Social Justice in (published version) Taxation (February 10, 2015). H.P. Gaisbauer et al. (eds.), Philosophical Explorations of Justice and Taxation (Springer International, 2015), 8398.

Publisher's Statement Reproduced with permission of Springer International

Always cite the published version, so the author(s) will receive recognition through services that track citation counts, e.g. Scopus. If you need to cite the page number of the author manuscript from TSpace because you cannot access the published version, then cite the TSpace version in addition to the published version using the permanent URI (handle) found on the record page.

This article was made openly accessible by $U$ of $T$ Faculty. Please tell us how this access benefits you. Your story matters. 


\title{
Chapter 6 \\ The Challenge of Tax Avoidance for Social Justice in Taxation
}

\author{
Benjamin Alarie
}

\begin{abstract}
The Occupy Wall Street (OWS) movement has been criticized for not having a tax policy agenda. Critics contend that it has "no message," "no goals," and "no leaders." This contribution accounts for this policy agenda deficit. Various tax policy prescriptions that address social resource inequality, including a wealth tax proposed by Pikkety and Goldhammer (Capital in the twenty-first century, 2014), suffer from serious weaknesses. More specifically, I explain why the most salient of the income tax policy ideas (increasing rates) is not, on its own, a solution. To see why, consider the US. The US has high corporate income tax rates; nevertheless, large American corporations such as Apple, GE, Starbucks and Google have been able to reduce their effective corporate income tax rate liability below statutory rates, often close to zero. The crux of the problem is that increasing income tax rates leaves those confronting such rates with greater incentive to engage in various activities in order to avoid those taxes. It also increases the return from lobbying for tax changes that make avoiding that burden more possible. Therefore, increasing income tax rates is not the clear-cut effective policy prescription one might think it should be. The example of the Bush tax cuts for individuals, and certain kinds of capital income, illustrates that cutting income tax rates is also not the right approach. In many countries, claims that cutting taxes will increase tax revenues (i.e., that we "are on the wrong side of the Laffer curve") are incorrect. Thus, if income tax rates are increased, it is not necessarily the wealthiest that will bear the greatest burden, and if tax rates are cut, it is not certain-or even particularly likely-that it will be the least well off who will benefit. OWS ought therefore not to be criticized for not articulating a message with respect to income tax policy. Recent developments show that popular political pressure on leaders has led the G20 to the right-albeit difficult - track. The best income tax reform is one of base broadening and increasing international tax cooperation, perhaps coupled with making a transition from reliance on income tax to a greater reliance on coordinated wealth taxes. Responding intelligently to demands for a more progressive tax system that promotes the realization of social justice will require us to confront difficult practical and political challenges. These tax policies are available only if the political will can be found to sustain their introduction and implementation.
\end{abstract}

B. Alarie (四)

Facutly of Law, University of Toronto, 84 Queen's Park, Toronto, ON M5S 2C5, Canada e-mail: ben.alarie@utoronto.ca 


\subsection{Introduction}

The Occupy Wall Street (OWS) movement seized headlines in September 2011 with the occupation of Liberty Square in Manhattan by hundreds of protestors. At the time, mainstream media featured interviews with OWS participants, many of whom aired different sets of grievances. External commentators were critical of the protest, not least because it was unclear what was being protested about and because there was no clarity as to what, moreover, would constitute success. One could plausibly put all this down to the difficulty of finding a sound bite that neatly captured the protest's origins and its goals. However, there may be an underlying reason why the impetus for the OWS movement could not adequately be expressed in sound bite form. In this contribution, I focus on the social justice dimension of tax policy in positive terms and provide an account of the challenges faced by the OWS movement in articulating tax policy goals. More specifically, I identify and describe a form of screening or second-degree price discrimination that is at the core of domestic and international income tax systems, and argue that this mechanism complicates measures that would seemingly address the economic inequalities that motivate the OWS movement. A similar mechanism would also impair the effectiveness of a wealth tax along the lines now suggested by Piketty and Goldhammer (2014), though less seriously.

What is it that provides fuel for the OWS movement in the tax policy context? One view is that it is a sense that the wealthiest are not paying their fair share of taxes. The feeling is linked to the perception that wealthy individuals and large corporations often have the motive and opportunity to influence the design of tax rules so as to minimize their tax burdens and, where the rules are ambiguous, engage in tax planning that ranges from run-of-the-mill compliance to aggressive tax avoidance (not to mention evasion). The irritation exhibited by the OWS movement with this perceived rigging of the tax law is understandable given that many of the most effective anti-avoidance tools, such as retroactive specific anti-avoidance rules, lie unused much of the time. Even when governments use such tools, they are usually deployed with a significant time lag after new tax avoidance strategies have come to light. Moreover, most of the time, tax law changes are effective only prospectively. This allows tax avoiders to retain their transitory tax savings. Thus, the popular discontent with tax avoidance evidenced by the OWS movement is in tension with governments choosing to countenance ongoing and significant forgone tax revenues. Some in the OWS movement resolve this tension by assuming that there are imbalances in the social, political and economic structure. Indeed, one gets the sense that some OWS protestors believe in something that amounts to an elite conspiracy. In my view, these suspicions are too extreme to be credible. I argue in this contribution that, although there is no elite conspiracy, there is an identifiable socio-political-economic dynamic that accounts for the perceived unfairness motivating the OWS movement. Unfortunately, responsibility for this dynamic is diffuse. No one party in particular is to blame, and the appropriate policy responses will be difficult to coordinate and sustain. The contribution here is to argue that 
once we correctly diagnose the underlying conditions, it will be possible to have a clearer view of how best to address the resulting consequences in a socially just and desirable way.

Two recent developments addressing tax avoidance are on the right track. The first is a report from the OECD (2013a) entitled "Addressing Base Erosion and Profit Shifting" (BEPS). The report advocates collective action by all OECD member governments to create similar, if not uniform tax rules to prevent corporations from shifting profits from higher tax to lower tax jurisdictions. The second recent development is the coordinated announcement on July 19,2013 by the finance ministers of the G20 of an "action plan on BEPS" that essentially adopts the OECD's recommendation of a fundamental rethink of international tax rules. While the report focuses primarily on profit shifting, a number of the corrective measures proposed could be extended to other forms of tax avoidance. The action plan (OECD $2013 b$ ) includes 15 different areas where tax rules need to be improved in order to mitigate tax avoidance and contemplates concerted action in these areas within 24 months. How likely is serious reform?

It is predictable that governments will tolerate tax avoidance until it becomes sufficiently visible to motivate political opposition or sufficiently widespread so as to significantly reduce tax revenues. If the BEPS action plan does yield tangible change-as seems possible-it will be a sign that the pendulum has swung too far in favour of tax avoidance. However, if the action plan does not yield aggressive anti-tax avoidance in an internationally coordinated way, it is likely that two accounts will be offered to justify its failure: justice and political economy. The first of these accounts, justice, invokes the rule of law to make the case that many of the most effective anti-avoidance strategies, such as retroactive legislation, are inherently antithetical to the principles and aspirations of modern legal systems and are, for that reason, off the table (except perhaps in the most exigent circumstances). The second account takes seriously the political economy hurdles militating against vigilance in enforcing tax laws. It may, for example, be extremely difficult to tackle aggressive tax avoidance because of the political clout of the economic interests favoured by inaction, or the practical difficultly of mobilizing tax authorities to revisit earlier tax assessments.

In what follows, the prospect for effective responses to concerns surrounding inequality is assessed against the backdrop of the political and economic realities of taxation. The result is an outline of the challenges for social justice in taxation. Part II provides a review of the literature on anti-avoidance. Part III elaborates on the rule of law and political economy accounts that provide an explanatory basis for anti-avoidance activity on the part of governments. Part IV describes the mechanism by which domestic and international income tax systems at their core depend (perhaps unintentionally) on screening and second-degree price discrimination, and explores the implications of this insight for the BEPS action plan, tax policy and administration more generally and, ultimately, for social justice in taxation. Part V concludes. 


\subsection{Literature Review}

The legal and economic literatures discuss how tax avoidance strategies are identified by taxpayers, why they are tolerated, and how governments ought to respond to them. In a recent contribution, Leo Katz (2010) argues that the tax system embodies the result of multi-dimensional decision-making where the government decides what to tax based on a number of different underlying legal and economic criteria, each of which is susceptible to some degree of manipulation by taxpayers. The key idea is that some of the criteria made legally relevant for assessing tax liability by the government are substantially irrelevant from the point of view of the potential taxpayer. As a result, the taxpayer can structure her affairs by adjusting the criteria that are most relied on by the government in assessing tax liability, but least harmful to her economic or personal objectives in the light of the reduction in tax liability that these adjustments will occasion. Katz's argument can be shown in a simple example. Suppose the government decides that dividend income from equity should be taxed, but interest payments on debt should not be. Assume that the criterion that this decision is based on is some non-tax benefit associated with the equity. An avoidance strategy forms as soon as there is a person who is indifferent to the benefit of the equity, as that person will simply choose the tax-free debt. This can be seen as a form of agenda manipulation because the inclusion of the irrelevant criteria leads the person to choose the non-tax route, i.e. the avoidance strategy.

In discussing the economic impact of government responses to various kinds of tax avoidance strategies, David Weisbach $(2002$, p. 90$)$ explains that anti-avoidance is simply a form of expanding the tax base. The consequences of tax avoidance can be viewed as false negatives - those who should be paying tax are not. In his view (99), the goal of anti-avoidance doctrines is to reduce the ability of taxpayers to substitute into non-taxed activities, thereby forcing them into compliance-making their actions true positives rather than false negatives. However, in many cases, anti-avoidance rules may shift taxpayers into less efficient tax avoidance schemes rather than into compliance; that is, instead of becoming true positives, taxpayers may simply go to even greater lengths to remain false negatives. This results in a loss of utility for the taxpayer with no offsetting benefit for the government. The logical response to this would be to increase the scope of the anti-avoidance doctrine to preclude the new form of avoidance. However, Weisbach (116) warns that this could then make the anti-avoidance rule too inclusive, and accidentally penalize people who are engaging in legitimate business transactions through the generation of an inefficient rate of false positives. Furthermore, the cost of creating and enforcing anti-avoidance doctrines is often high. In essence, Weisbach's argument is that due to uncertain taxpayer responses, it is often unclear whether the benefits of an anti-avoidance measure will outweigh its costs of enforcement.

Leigh Osofsky (2013, p. 1058) raises a similar argument to Weisbach regarding the structure of avoidance rules. She notes that, ideally, avoidance rules should create frictions that make it more costly for tax avoiders to avoid taxes, which forces them to comply. However, poorly constructed avoidance regimes might also lead to 
a deadweight loss for non-planners, or result in the planners finding a more costly method of avoidance. Thus, the existing literature suggests that there are some circumstances in which full enforcement of tax laws is not desirable.

The account that I develop here shows that the problems of full enforcement are linked to a form of screening mechanism that is similar to second-degree price discrimination. A number of contributions by Alex Raskolnikov implicitly recognize aspects of this kind of screening function. Raskolnikov (2009, p. 695) suggests that there are two kinds of taxpayers: gamers, and non-gamers. Gamers are the neo-classically "rational" taxpayers, who avoid taxes as long as the cost of avoidance is less than the cost of compliance. Non-gamers generally comply with taxation, even if it can be avoided at a cost less than paying tax. Raskolnikov (691) argues that the American tax system adopts a one size fits all approach to tax law enforcement, resulting in the inefficient treatment of both gamers and non-gamers. In its place, Raskolnikov suggests a system that causes taxpayers to self-select in an incentive-compatible way into a particular enforcement regime, with the result that gamers and non-gamers self-identify. The government would then offer two parallel systems, one that is best for gamers, and one that is best for compliers. Take for example a simplified version of Raskolnikov's regime. The government would offer a system similar to the current deterrence approach, as well as an alternative filing option with lower penalties. The low-penalty option would presume that the government is correct in the event of a tax dispute. Those who comply do not mind this presumption since they do not expect a dispute, and therefore elect to take advantage of the lower penalties. Gamers, on the other hand, expect a dispute to be more likely, and do not choose the alternative option. Thus, as a consequence of this self-selection, the government would be able to introduce tailored and efficient enforcement policies for each taxpayer type.

Raskolnikov (2006, p. 590) also argues that current deterrence regimes are ineffective because the available penalties do not vary with probability of detection. As such, the expected penalty of avoidance methods that are difficult to detect is quite low, since the magnitude of the penalty is no larger than most other avoidance methods. These flaws make enforcement strategies less effective at catching or deterring tax avoiders. Extending Raskolnikov's work perhaps explains some of the tolerance towards tax avoidance, as the ineffectiveness of anti-avoidance rules could be a reason why they are not used more often. Raskolnikov's assumption that taxpayers exhibit differing levels of responsiveness to tax liability has empirical support. Empirical work has found that effective tax liability does track the morale of taxpayers with respect to taxation. For example, Doerrenberg et al. $(2012$, p. 1) found that governments are likely to tax citizens based on levels of "tax morale" (a taxpayer's "intrinsic motivation to honestly pay taxes"). They also suggest that tax morale is a suitable proxy for proclivity for tax avoidance. The result of these two ideas is that governments are likely to tax those who are least likely to take measures to avoid taxation at the highest rates-an implicit recognition of the screening function at the core of domestic and international income tax systems.

This finding is also consistent with theoretical work done by Hettich and Winer (1999, p. 46) who present a model of a democratic government with a governing 
party that wishes only to be re-elected. Voters have different valuations of government services, which lead them to support the government, and different reactions to taxes, which make them likely to oppose the government. The optimal solution makes the "marginal political cost"-which is understood as the reduction in expected votes of raising an additional dollar in revenue-the same for all taxpayers. As a result, under this system, the financing of beneficial government services will largely be borne by those taxpayers whose political preferences are the least likely to be affected by increases in their tax burden. This maximizes the probability of the government being re-elected. While this model does not explicitly discuss tax avoidance, it can easily be extended to do so. The model assumes that the government has perfect information and can tax individuals at their exact marginal political cost. However, information asymmetries exist in the real world. Tolerating tax avoidance is therefore one way that a government could encourage taxation at a level close to the marginal political ,cost for each taxpayer, as the more tax averse will end up with lower taxes. Under the extension of this model, the government can be seen to tolerate tax avoidance in the government's own self-interest.

Brennan and Buchanan's The Power to Tax is a precursor to these more recent works. Brennan $(2000, p$. xiii) states that the object of the book was to fill the gap between the only two available normative tax theories at the time, the public choice model and the public finance model. The result is a Leviathan model, which features a government that seeks only to maximize its revenue, and is subject to few constraints. This work is important not only because it showed that taxation could be examined outside of the constraints of the original models, but also because the Leviathan model itself has current implications. For example, while Hettich and Winer reject the Leviathan model, they implicitly adopt the underlying logic of taxing based on price discrimination, which the Leviathan model uses to maximize revenue. The Leviathan model is closely related to the story of second-degree price discrimination that I use to assess the BEPS action plan below.

\subsection{Anti-Avoidance: Justice and Political Economy}

There are at least two accounts of why governments do not do more to counter tax avoidance. The first account highlights the rule of law as a disciplining mechanism on the kind of aggressive responses that might be necessary to stem tax avoidance in a system with high tax rates. The second account highlights the political environment that might render an otherwise effective response to tax avoidance politically or economically inadvisable.

Friedrich August Hayek (2007, p. 112) articulated the concept of the rule of law as follows, "stripped of all technicalities this means that government in all its actions is bound by rules fixed and announced beforehand-rules which make it possible to foresee with fair certainty how the authority will use its coercive powers in given circumstances, and to plan one's individual affairs on the basis of this knowledge." More recently, credit for popularizing the concept of the rule of law is often 
given to British jurist Albert Venn Dicey. Dicey described three distinct meanings for the phrase "the rule of law." Only the first of these meanings is directly relevant to taxation. The primary meaning Dicey $(1897$, p. 197) gave to the rule of law is that, "no man is punishable or can be made to suffer in body or goods except for a distinct breach of law established in the ordinary legal manner before the ordinary courts of the land." Rawls built on Dicey's account, and subsequently identified five requirements of the rule of law: (1) compliance must be possible; (2) there must be regularity; (3) there must be publicity; (4) there should be generality to law; and (5) there must be respect for due process (Solum 2009). ${ }^{2}$

Joseph Raz (1977) has also articulated an influential set of requirements of the rule of law. ${ }^{3}$ Others, including Lon Fuller (1969), have also attempted similar lists.

While there has been some writing in the academic tax literature on the rule of law, it is relatively limited. Geoffrey Loomer (2006) argued in an article in the British Tax Review that unwritten constitutional principles relating to the rule of law might well legitimately constrain the domain for Parliament to respond with retroactively effect tax legislation. In another recent publication, Thomas E. McDonnell (2006) argues that, in the taxation context, the rule of law can be regarded as entailing four specific consequences with respect to retroactive legislation: "(1) that curative amendments are always acceptable; (2) that a taxpayer who has reasonably relied on the state of the existing law has an interest worthy of consideration, depending on the degree of reasonable reliance involved; (3) that the concept of fairness should be understood as applying to all taxpayers generally and not just to members of a group adversely affected by a retroactive change; and (4) that fiscal considerations in and by themselves should never be relied on in support of a retroactive change."

The upshot of both the more general philosophical accounts of the demands of the rule of law and the writings that are more practical and focused on the taxation context is that retroactive legislation that violates the legitimate expectations of taxpayers is impermissible. This raises a number of questions, however, surrounding just what precisely constitutes the legitimate expectations of taxpayers when taxpayers are engaged in tax avoidance, and whether the described impermissibility is absolute or only cautionary. It is enough, however, to emphasize that retroactive laws are generally inconsistent with demands that the law be knowable ex ante so that it can reliably guide taxpayer behaviour.

The political economy perspective can be ably summarized by an aphorism attributed to Jean-Baptiste Colbert: "the art of taxation consists in so plucking the goose as to obtain the largest amount of feathers with the least amount of hissing" (Yablon 2006, p. 123). ${ }^{4}$ There are several ways in which the political economy

'For a discussion of Dicey's contributions to the popularization of the idea of the rule of law, see (Cosgrove 1980).

${ }^{2}$ For a brief but instructive elaboration on these five elements, see (Solum 2009).

${ }^{3}$ Among these general principles for $\operatorname{Raz}$ (1977, are that "all laws should be prospective, open and clear" and that "laws should be relatively stable."

${ }^{4}$ This is an old French maxim, often attributed to Jean-Baptiste Colbert (1619-1683). 
environment affects the timing of government responses to tax avoidance. ${ }^{5}$ The most significant is likely to be the collective action problem that arises as a consequence of the fact that the loss to the public purse from tax avoidance is normally felt diffusely and usually remotely in time, whereas the gain to the taxpayer from tax avoidance is immediate, direct and often personal. ${ }^{6}$ Overcoming this collective action problem, however, involves confronting numerous obstacles from an administrative standpoint. For example, whereas each taxpayer is ideally situated to know the information that affects his or her tax situation, it is considerably more difficult for the government to monitor the information that pertains to each taxpayer's liability. Moreover, unlike a purely rational taxpayer, who would be willing to pay up to the amount of their tax liability in avoidance costs, governments are generally willing to expend lesser resources on auditing and enforcing income tax laws. Thus, there are three asymmetries that contribute to the phenomenon of tax avoidance: (1) an asymmetry in the concentration of stakes (diffuse for government versus concentrated for taxpayers); (2) an asymmetry in information (typically less for governments versus more for taxpayers); and (3) an asymmetry in the resources devoted by governments in enforcement and taxpayers in avoidance (less on enforcement by governments and more by taxpayers in avoidance).

These three asymmetries play out in a number of ways. Consider that for any individual employee of the tax administration, it will naturally be the case that the taxpayers that they interact with will be more keen to avoid additional tax liability than the employee will be to enforce the tax law to its full extent (though they may well be eager to do so, they will be less so than they would if they were personally allowed to keep in full whatever is recovered from the taxpayer in tax, interest, and penalties). While most tax administrators are honest and dutiful servants, this difference in incentives can reasonably be expected to manifest itself in suboptimal exertion on investigation and enforcement of the tax law. It is easiest to imagine this suboptimal enforcement in the context of a negotiated settlement to a dispute regarding an alleged underpayment of tax. In these circumstances, the prediction is that the settlement will, tend all other things being equal, to favour the taxpayer (relative to what the outcome would on average be in judicial proceedings).

Moving from tax administration to tax legislation, governments are likely to be slower than taxpayers in the tax avoidance context. When creative tax planners devise a new unanticipated scheme that manages to avoid tax under plausible interpretations of current income tax law, it is reasonable to expect these innovations to spread relatively quickly within the tax planning community (most obviously often within the same law firm or accounting firm). This contributes to the growth of tax avoidance and, if governments are not responding with counter-measures that are carefully calibrated to match threats, the resulting equilibrium will favour sophisticated taxpayers who will constantly be innovating in the tax avoidance con-

\footnotetext{
${ }^{5}$ For a book length treatment addressing a number of these issues, see (Aaron and Slemrod 2004).

${ }^{6}$ In an influential contribution, political scientist Terry M. Moe (1989, p. 273) wrote that, "American public bureaucracy is not designed to be effectivc. The bureaucracy arises out of politics, and its design reflects the interests, strategies, and compromises of those who exercise political power."
} 
text in order to respond to competitive pressures in product and capital markets. It will only be when governments act collectively and effectively with respect to both domestic and international tax rules that the resulting equilibrium will be socially satisfactory.

\subsection{Screening, Tax Avoidance and Social Justice}

Adopting a screening account of tax avoidance generates considerable new insight into the dynamic which complicates the development of a more progressive tax system. In order to explain the operation of this price discrimination mechanism in the context of income taxation, this part begins by describing the three principal types of price discrimination that have been identified by economists. The argument proceeds to examine the main modifications that must be made to the usual producer-consumer paradigm of price discrimination models in order to apply the screening implications to the domestic and international income tax setting. With the screening / price discrimination argument in place, this part concludes with the implications for social justice in taxation.

A leading economics text on industrial organization states that, "It is hard to come up with a satisfactory definition of price discrimination. Roughly, it can be said that the producer price-discriminates when two units of the same physical good are sold at different prices, either to the same consumer or to different consumers" (Tirole 1988, p. 133). First-degree or "perfect" price discrimination occurs when a producer is able to precisely identify each consumer's willingness to pay for the goods or service and can prevent the resale of the goods or the service in a secondary market. In these circumstances, a profit-maximizing producer will choose to charge each consumer a price equal to their maximum willingness to pay. In doing so, the producer will supply the entire market in a manner that will ensure economic efficiency and extract all available consumer surplus from the purchasers of the goods or service. To be operational, perfect price discrimination requires that strong assumptions be made. Specifically, the producer of the goods or supplier of the relevant service must have complete information about the willingness of consumers to pay and it must be possible to prevent arbitrage in the secondary market for the goods or service. Perfect price discrimination is, for that reason, largely regarded as being of theoretical interest rather than an empirically realistic phenomenon.

Second-degree price discrimination occurs when the producer has incomplete information about the preferences of particular consumers and cannot reliably target individuals or groups of consumers for particular pricing strategies. The producer will, in general however, have information about the mix of consumer preferences in the population. Therefore, unlike perfect price discrimination, where the producer knows precisely the willingness to pay of each consumer, in second-degree price discrimination the producer is aware only of the distribution of willingness to pay among consumers. In these circumstances, the goal of the producer is to induce consumers with different willingness to pay to choose different price-quantity bundles 
from a menu of options offered by the producer. If the producer is successful in setting a menu of price-quantity bundles that causes consumers with different willingness to pay to choose different bundles, then the producer will secure a greater share of the consumer surplus than uniform pricing would facilitate. Naturally, inducing the separation of consumers into different consumption bundles requires incentivecompatibility between the bundles on offer and the willingness to pay of each consumer. An example of second-degree price discrimination is a coupon that entitles the bearer of the coupon to a discount. It will systematically tend to be the case that more price sensitive consumers will make use of the coupon.

Third-degree price discrimination relies on an exogenous attribute of consumers that can be observed by the producer that is correlated with the consumers' willingness to pay. Unlike second-degree price discrimination, where the distribution of willingness to pay among consumers is known, but nothing is known about the willingness to pay of any particular consumer, in third-degree price discrimination, the producer is able to observe certain attributes of consumers that are linked to higher or lower willingness to pay for the goods or service. An example of third-degree price discrimination would be discounts that are made available only to seniors or students. If seniors or students have systematically lower willingness to pay for a particular good or service, and yet are still willing to pay enough to cover the marginal cost to the producer of the goods or service, it will be profitable for the producer to service the customers by allowing them to self-identify as members of the relatively low willingness to pay group.

It is possible to translate these three types of market-based price discrimination into versions that correspond with the task facing governments in setting the various structural features of domestic and international income tax law. For the purposes of the screening account, the translation requires the government to take on the role of the producer. The central challenge is that, unlike a private producer who can be assumed to be seeking to maximize profit, it is not at all obvious that the government's objective function corresponds to maximizing its tax revenues. Because of this, there must be an assumption made about how much revenue the government desires to raise through the income tax system. The simplest approach, which will be the one adopted here for the purposes of exposition, is to assume that the expenditure determination is independent and exogenously given. This assumption, while artificial, yields the reasonable result that the government's objective in structuring income tax is to collect a certain set amount of tax revenue in the "best" way possible. For a price discriminator, the "best" way involves charging consumers in a tailored fashion according to their willingness to pay, thereby capturing the maximum amount of surplus from consumers. While a government using price discrimination taxation may not be seeking to maximize its tax revenue, it will still tax based on the willingness to pay of taxpayers. In doing so, the government will capture the specified amount of revenue in the most efficient manner possible. The price discriminator, therefore, will charge more to consumers or taxpayers who place a higher value on the product or on compliance. As a result, those with higher tax morale and greater inclination to comply will pay more tax. This is an empirical as well as a theoretical outcome, and is supported by work by Doerrenberg. 
On the taxpayer's side, there is also a significant modification that must be made to the conventional price discrimination account. Here the issue is that taxpayer preferences do not yield a demand function of the kind typically associated with price discrimination models. In most models of price discrimination, consumers are assumed to exhibit declining willingness to pay for each additional unit of the goods or service provided by the producer. Because there is no explicit quid pro quo in income taxation, it is not possible to derive this kind of demand function directly on the taxpayer side. It is, however, possible to substitute a measure of taxpayer responsiveness for the more conventional demand function. By responsiveness I mean to refer to the extent to which taxpayers, either directly or, more commonly, by proxy through a tax adviser, respond in various ways to mitigate their effective tax obligations. Responsiveness is composed of three factors: the economic fundamentals of the taxpayer and the taxed activity, the willingness to comply, and the ability to use the tax system to avoid taxation.

Economic fundamentals matter because the nature of a taxpayer's economic activities will affect the ability of that individual or corporation to manipulate their legal relationships to mitigate their effective tax obligations. In particular, not only is it easier for taxpayers to respond to taxes on some sources of income than it is on others, the ability of taxpayers to respond to a tax on a particular source of income is also affected by the nature of their economic activities. For example, for some taxpayers, especially those with operations that span multiple jurisdictions, the most natural way to respond to changes in their tax liability will be to relocate their income-earning operations to another jurisdiction, either directly or indirectly. However, many taxpayers who wish to take advantage of such a response may be unable to do so if their operations are contractually simple or limited to one jurisdiction. Moreover, while taxpayers can undoubtedly mitigate their effective tax obligations purely by adjusting the economic substance of their taxable activities, for example, by electing to work less, doing so without any corresponding change in the legal nature of their economic arrangements will occasion an economic distortion and result in a loss of utility for the taxpayer. As a result, taxpayers will vary in their ability or willingness to increase or decrease the amount they work in response to taxation. To the extent that taxpayers are motivated to actually reduce their exposure to income tax through various behavioural channels, including shifting income to other jurisdictions, engaging in various tax avoidance transactions and, perhaps most worryingly from a social welfare perspective, simply deciding to be less productive by substituting leisure for labour, they are being responsive in the sense intended by the word. For many taxpayers, however, the economic fundamentals of their situation grant them little scope for rearranging their income-earning activities so as to mitigate an enhanced tax liability.

Personal values are a key component of taxpayer responsiveness. The perfectly rational and self-interested taxpayer is willing to spend up to a dollar avoiding each dollar of tax. However, taxpayers are not always rational in this way, and routinely pay more than would be expected by neoclassical economists. ${ }^{7}$ Less responsive

\footnotetext{
${ }^{7}$ The work of Erich Kirchler in economic psychology demonstrates this in the taxation setting.
} 
taxpayers may stray from the economic definition of rationality due to their social identity, attitude towards government, or an expected sense of shame if they are caught avoiding taxes. While most of the literature and empirical evidence suggests that individuals avoid taxes to a lesser extent than would be expected pursuant to rational self-interest, it is also possible that someone could avoid more than the rational amount of tax. As an extreme example, a libertarian might be willing to pay more in avoidance costs than would be saved in taxes. The most radical legal response is exiting the tax system altogether, such as by leaving the jurisdiction or ceasing to work entirely. The idea that one's personal values can cause a decision to deviate from the economically rational choice is not new. Albert Hirschmann (1970) noted forty years ago that many consumers have an attachment or loyalty to brands that prevents them from exiting as a consumer of that brand even when it declines in quality relative to identical competitors. The same reasoning extends to taxation. Taxpayers who have a high degree of loyalty to their country of residence will be more willing to pay taxes and less likely to exit the jurisdiction and vice versa.

Responsiveness is also influenced by the skill or ability of taxpayers to employ methods of reducing taxation. In a sense, ability brings together the other components of responsiveness, allowing taxpayers to reduce their taxes to the desired extent by taking advantage of the economic fundamentals of their situations. Ability can either be either direct or by proxy, for example, by hiring a tax professional or purchasing tax software. Stylistically and for the purposes of exposition, one can imagine taxpayers falling into one of three groups: (1) sophisticated taxpayers; (2) taxpayers of ordinary sophistication; and (3) less sophisticated taxpayers. Although these categories are apt to be somewhat inexact, it is possible to differentiate among them as follows. The most sophisticated group of taxpayers understands that the income tax system is complicated and that this complexity comes with both opportunities and pitfalls. The hallmark of the most sophisticated group is, therefore, an ability to proactively manage and plan their income-earning activities in order to minimize their tax liabilities. In doing so, sophisticated taxpayers will typically retain elite tax professionals who assist them in developing plans to minimize their tax liabilities. The majority of taxpayers, of course, will not be highly sophisticated and, out of necessity, will tend to be reactive rather than proactive with respect to their tax obligations. Taxpayers in this group will not generally be forward-looking in managing and planning their income-earning activities, and will instead focus on complying ex post with their tax obligations each year. Most small and medium sized businesses and middle to high income taxpayers will properly be regarded as being of ordinary sophistication. When taxpayers of ordinary sophistication hire tax advisors or consult resources, they most often turn to non-elite tax sources of tax advice, such as tax preparation services, small accounting firms, or software programs. Another group of taxpayers is less sophisticated still. For these individuals, the demands of the income tax system are intimidating and sometimes overwhelming. These taxpayers are generally of more limited means, less well educated, and often have more significant challenges (or at least challenges that loom larger) than tax compliance. It should be clear from this account that taxpayers of ordinary and low sophistication are unlikely to be responsive to (or, realistically, to be much af- 
fected by) legislative changes addressing tax avoidance. Instead, taxpayer responsiveness to anti-avoidance measures is largely a phenomenon involving highly sophisticated taxpayers.

Put simply, the solution offered to the translation from consumer to taxpayer is to replace the usual measure of consumer preferences, the demand function, with a function representing the responsiveness of taxpayers to higher prima facie income tax burdens. The idea of taxing people differently based on their responsiveness to taxation is not novel. Hettich and Winer demonstrate how a government can tax individuals based on the probability that the tax level will cause them to vote for the opposing party in the next election. That model assumes perfect information, allowing the government to set a tax rate exactly equal to an individual's willingness to pay tax. While perfect information is a useful assumption for modelling purposes, it rarely exists in real life. One of the benefits of the price discrimination approach is that second-degree price discrimination allows the government to tax people in this manner without actually knowing each individual's responsiveness.

In order to analyse the application of ideas taken from the industrial organization literature relating to price discrimination in the income taxation context, it will be helpful first to set out how second-degree price discrimination can be translated into the income tax environment. To the extent that governments can anticipate a certain distribution of responsiveness to income taxation in a given group, but are unable to identify exante who among that group will be more or less responsive, there may be scope for second-degree price discrimination. As mentioned above, for second-degree price discrimination to be effective, there must be a common set of options that are available to all taxpayers such that taxpayers of different responsiveness respond predictably differently. One way that a government might achieve this outcome is by setting out a relatively high "advertised" tax rate that applies on a tax base that is common to all taxpayers. Because in the abstract all taxpayers will be governed by the same set of rules, one can regard this as an invitation to taxpayers to choose among the tax treatments permitted by the legislation. In such a case, highly responsive taxpayers will be able to proactively manage their income tax burden through innovative tax avoidance measures (shifting income to other jurisdictions, using sophisticated tax shelters, etc.) more easily than will low responsiveness taxpayers. As a result, highly responsive taxpayers will usually be able to help themselves to effective tax rates that are lower than the effective tax rates that will apply to low responsiveness taxpayers. There may be social welfare gains from this kind of system since this form of screening or price discrimination will tend to promote a better correspondence between the marginal welfare loss to each taxpayer from taxation and the marginal social gain in government expenditures than would be associated with an income tax system that did not permit this kind of screening. Moreover, this price discrimination mechanism is advantageous to the extent that it provides a variety of tailored options to taxpayers. A taxpayer without a viable avoidance strategy would have to choose between paying full taxes and engaging in an economically detrimental activity such as working less, or exiting the jurisdiction altogether. Adding price discrimination as an option makes exiting a relatively less attractive option to the taxpayer as she can remain in the 
jurisdiction and escape some taxation. Therefore, to the extent that it is realistic to believe that there will be a group of sophisticated taxpayers amongst whom it will be difficult for the government to discriminate explicitly, then there will be a case for price discrimination in income taxation.

Stylistically, there is a stark choice confronting domestic and international tax policymakers emerging from the foregoing account. The choice is between (1) a dynamic higher rate income tax system with an active yet flexible approach to tax avoidance; and (2) a less flexible lower rate income tax system with a relatively strict approach to tax avoidance. Because most tax systems have decided not to rely extensively on retroactive specific anti-avoidance rules or multiple alternative tax bases, I suggest that it is clear that most governments can be characterized as having embraced the first choice.

If the government's aim is to raise a certain targeted amount of revenue, in the long-run there is not likely to be a third option in which the tax system has both low tax rates and a flexible approach to tax avoidance. However, depending on the tax systems adopted by other jurisdictions, it is possible that such an option might be available in the short-run. For example, in the transfer pricing context, it is likely that the country with the lowest effective tax rate for business income will generate more revenue because of income-shifting into the jurisdiction from higher tax rate jurisdictions. Why will this not work in the long-run? Because the revenue gains will largely be transitory, even if they do happen to be repeated transitory gains in a race to the bottom. Indeed, if a jurisdiction becomes accustomed to such "incomeshifting" tax revenue, it should not be surprised if it becomes a participant in a race to the bottom that will-if the strategy is not abandoned-lead to it becoming insolvent (or a tax haven).

Thus, from the international and collective perspective, the only real choice is to embrace the reality that relatively high rate income tax jurisdictions will need to work together to be more dynamic, flexible and responsive in exerting counteracting pressure on taxpayers advised by leading accounting and law firms. While the appropriate policy responses, including expanding the tax base and increasing international tax cooperation, will not eliminate the deleterious effects of the price discrimination mechanism, there is no long-run alternative that will preserve social justice. It is only with constant partial enforcement of anti-avoidance measures that governments that are aware of the second-degree price discrimination mechanism at the core of their tax system can maintain their revenues. As such, governments must be constantly on guard against being too permissive or too draconian with respect to tax avoidance. In these circumstances, it is clear why governments might simultaneously complain about tax avoidance while not pursuing all measures legally available to combat it.

It is, incidentally, in the best interests of sophisticated taxpayers not to overplay their hands. The leading tax advisers in law and accounting firms recognize that it is appropriate to foster a tension between tax planning and the responses taken by governments domestically and internationally. An enlightened pragmatism suggests that it is better for both governments and sophisticated taxpayers to be mutually plucking geese with a minimum of squawking. To mix metaphors, the awkwardly 
effective tax strategies of GE, Google, Apple and others may take the plucking of feathers from the coffers of governments too far.

It will be interesting to see what comes of the BEPS action plan recently endorsed by the finance ministers of the G20. Popular discontent with the growing levels of income and wealth inequality in many countries suggests that there is an imbalance between the degree of tax avoidance now achieved by many sophisticated taxpayers and the tax collection by governments to support expenditures that are socially just and in the public interest. Neither governments nor taxpayers should be given an easy ride in avoiding tax or in imposing taxes.

\subsection{Conclusions}

It will be difficult to achieve social justice in taxation without recognizing that income tax systems act as a second-degree price discrimination mechanism through which the most sophisticated and responsive taxpayers self-select into lower effective income tax rates and less responsive taxpayers are left facing relatively higher income tax liability. Although some solutions would gain more traction than others were they to be adopted - the global wealth tax of Piketty (2014) is one such idea-in all likelihood a global tax on capital is, as Piketty acknowledges (515), a "utopian idea."

To minimize the deleterious effects of the self-selection and other avoidance mechanisms described in this chapter, governments must remain cognizant of the screening function and be ever vigilant in working together to sustain optimal antitax avoidance pressure. The OWS movement and BEPS initiative of the G20 thus face significant challenges, the most considerable of which is sustaining the political will necessary to tackle the difficulty associated with the price discrimination mechanism that lies at the heart of systems of domestic and international income taxation. In a world of scarcity, pragmatic taxpayers, governments and voters must work together respectfully in common cause to realize economic, political and social justice.

\section{References}

Aaron, Henry J, and Joel Slemrod, eds. 2004. The crisis in tax administration. Washington, D.C.: Brookings Institution Press.

Brennan, Geoffrey, and James M. Buchanan. 2000. The power to tax: Analytical foundations of a fiscal constitution. Indianapolis: Liberty Fund.

Cosgrove, Richard A. 1980. The rule of law: Albert Venn Dicey, Victorian jurist. London: Macmillan.

Dicey, A. V. 1897. An introduction to the study of the law of the constitution. 5th ed. London: Macmillan.

Doerrenberg, Phillip, Denvil Duncan, Clemens Fuest, and Andreas Peichl. 2012. Nice guys finish last: Are people with higher tax morale taxed more heavily? IZA Discussion Paper Series, No. 6275 . 
Fuller, Lon L. 1969. The morality of law. Rev ed. New Haven: Yale University Press.

Hayek, Friedrich A. 2007. The road to serfdom: Text and documents, the definitive edition, ed. Bruce Caldwell. Chicago: University of Chicago Press (Orig. pub. 1944).

Hettich, Walter, and Stanley L. Winer. 1999. Democratic choice and taxation: A theoretical and empirical analysis. Cambridge: Cambridge University Press.

Hirschman, Albert O. 1970. Exit, voice, and loyalty: Responses to decline in firms, organizations, and states. Cambridge: Harvard University Press.

Katz, Leo. 2010. A theory of loopholes. Journal of Legal Studies 39 (1): 1-31.

Loomer, Geoffrey. 2006. Taxing out of time: Parliamentary supremacy and retroactive tax legislation. British Tax Review 1:64-90.

McDonnell, Thomas E. 2006. Retroactivity: policy and practice. In Report of proceedings of the fifty-eighth tax conference, 2006 Conference Report, 2:1-33. Toronto: Canadian Tax Foundation.

Moe, Terry M. 1989. The politics of bureaucratic structure. In Can the government govern? eds. John E. Chubb and Paul E. Peterson, 273-329. Washington, D.C.: Brookings Institution Press.

OECD. 2013a. Addressing base erosion and profit shiffing. OECD Publishing. http://dx.doi. org/10.1787/9789264192744-en. Accessed 4 Dec 2014.

OECD. 2013b. Action plan on base erosion and profit shifting, OECD Publishing. www.oecd.org/ ctp/BEPSActionPlan.pdf. Accessed 4 Dec 2014.

Osofsky, Leigh. 2013. Who's naughty and who's nice? Frictions, screening, and tax law design. Buffalo Law Review 61 (5): 1057-1117.

Piketty, Thomas, and Arthur Goldhammer. 2014. Capital in the tweenty-first century. Cambridge: Harvard University Press.

Raskolnikov, Alex. 2006. Crime and punishment in taxation: Deceit, deterrence, and the self-adjusting penalty. Columbia Law Review 106 (3): 569-642.

Raskolnikov, Alex. 2009. Revealing choices: Using taxpayer choice to target enforcement. Columbia Law Review 109 (4): 689-754.

Raz, Joseph. 1977. The rule of law and its virtue. Law Quarterly Review 93 (2): 195-211.

Solum, Lawrence B. 2009. Legal theory lexicon: The rule of law. http://solum.typepad.com/legaltheory_lexicon/2004/01/legal_theory_le_3.html. Accessed 4 Dec 2014..

Tirole, Jean. 1988. The theory of industrial organization. Cambridge: MIT Press.

Weisbach, David. 2002. An economic analysis of anti-tax-avoidance doctrines. American Law and Economics Review 4 (1): 88-115.

Yablon, Jeffery L, comp. 2006. Certain as dcath-Quotations about taxes 110 tax notes 103 . 